\title{
MENEROPONG PRINSIP NON INTERVENSI YANG MASIH MELINGKAR DALAM ASEAN
}

\author{
Erika \\ Fakultas Hukum Universitas 17 Agustus 1945 Samarinda \\ e-mail: erika_notaris@yahoo.com \\ Dewa Gede Sudika Mangku \\ Fakultas Ilmu Sosial Universitas Pendidikan Ganesha Singaraja Bali \\ e-mail: dewamangku.undiksha@gmail.com
}

\begin{abstract}
ABSTRAK
ASEAN didirikan berdasarkan Deklarasi Bangkok pada tanggal 8 Agustus 1967, dengan beranggotakan sepuluh negara di kawasan Asia Tenggara yang masih tetap berpegang teguh pada prinsip non intervensi yang telah diatur dalam Treaty of Amity and Cooperation in Southeast Asia 1976 (TAC) dan Piagam ASEAN. ASEAN berkembang menjadi suatu organisasi internasional besar dan mulai diperhitungkan dalam dunia internasional, prinsip non intervensi masih menjadi suatu permasalahan yang masih melingkar dalam tubuh ASEAN dan sudah seharusnya para pemimpin ASEAN untuk memikirkan suatu fleksibelitas dari suatu prinsip ini, hal ini bertujuan untuk membantu suatu negara anggota yang tengah dihadapi permasalahan khususnya tentang kemanusiaan.
\end{abstract}

Kata Kunci: ASEAN, Prinsip Non Intervensi, TAC, dan Piagam ASEAN.

\section{ABSTRACT}

ASEAN was established by the Bangkok Declaration on August 8, 1967, with the region of ten countries in Southeast Asia that still remains on the principle of non-intervention which has been arranged in the Treaty of Amity and Cooperation in Southeast Asia in 1976 (TAC) and the ASEAN Charter. ASEAN grown into a large international organization and gained recognition in the international world, the principle of non-intervention is still a problem that still coiled in the body of ASEAN and the ASEAN leaders ought to think about the flexibility of this principle, it aims to help a country members who were in face particular problems of humanity.

Keywords: ASEAN, Principles of Non-Intervention, TAC and ASEAN Charter.

\section{PENDAHULUAN}

Association of Southeast Asian Nations (yang selanjutnya disebut ASEAN) adalah organisasi internasional yang dibentuk oleh lima Negara dan telah beranggotakan sepuluh Negara di kawasan Asia Tenggara. Selama terbentuknya ASEAN telah banyak suatu permasalahan yang telah dilalui oleh organisasi yang dibentuk berdasarkan Deklarasi Bangkok tahun 1967 ini. ASEAN dari awal terbentuknya hingga saat ini masih memegang teguh prinsip non intervensi atau prinsip tidak ikut campur urusan dalam negeri masing-masing Negara anggotanya. Hal ini terlihat di dalam perjanjian-perjanjian internasional yang telah ditandatangani oleh seluruh anggota-anggota ASEAN, misalnya dalam Treaty of Amity and Cooperation in Southeast Asia 1976 (TAC) serta Piagam ASEAN dan terdapat dalam prinsip-prinsip ASEAN.

ASEAN merupakan organisasi internasional yang berada di kawasan Asia Tenggara, dimana organisasi regional ini dibentuk pada tanggal 8 Agustus $1967 \mathrm{di}$ Bangkok berdasarkan Deklarasi Bangkok oleh lima Negara pendiri yaitu Indonesia, Malaysia, Filipina, Singapura dan Thailand. Suatu organisasi didirikan memiliki maksud dan tujuannya, begitu juga terhadap ASEAN yang kehadirannya sangat dinanti-nanti di Kawasan Asia Tenggara, sebab hal ini sangat penting untuk dapat menjembatani setiap hubungan diplomatik 
di antara para anggotanya. Salah satu poin penting tujuan didirikan ASEAN adalah memelihara dan meningkatkan perdamaian, keamanan, dan stabilitas serta lebih memperkuat nilai-nilai yang berorientasi pada perdamaian di kawasan serta menjamin bahwa rakyat dan Negara-Negara anggota ASEAN hidup damai dengan dunia secara keseluruhan di lingkungan yang adil, demokratis dan harmonis. Sesuai dengan rumusan Pasal 4 Deklarasi Bangkok, keanggotaan ASEAN terbuka bagi Negara-Negara Asia Tenggara lainnya dengan syarat bahwa Negara-Negara calon anggota menyetujui dasar-dasar dan tujuan organisasi ASEAN seperti yang tercantum dalam Deklarasi ASEAN dan semua traktat atau persetujuan yang dibuat dalam kerangka ASEAN. Keanggotaan ASEAN kemudian bertambah menjadi sepuluh Negara anggota dengan masuknya Brunei Darussalam, Vietnam, Laos, Myanmar, dan Kamboja.

Brunei Darussalam secara resmi diterima menjadi anggota ke-6 ASEAN pada tanggal 7 Januari 1984, dalam Sidang Khusus Menteri-Menteri Luar Negeri ASEAN di Jakarta, Vietnam diterima menjadi anggota ke-7 ASEAN dalam Pertemuan Para Menteri Luar Negeri (AMM) ke-28 pada tanggal 29-30 Juli 1995 di Bandar Seri Begawan. Laos dan Myanmar diterima sebagai anggota penuh ASEAN melalui suatu upacara resmi pada tanggal 23 Juli 1997 dalam rangkaian Pertemuan Para Menteri Luar Negeri ASEAN (AMM) ke-30 di Subang Jaya, Malaysia, tanggal 23-28 Juli 1997. Kamboja diterima sebagai anggota penuh ASEAN pada upacara penerimaan resmi di Hanoi tanggal 30 April 1999. Dengan diterimanya Kamboja, maka citacita para pendiri ASEAN untuk mewujudkan ASEAN yang mencakup sepuluh Negara Asia Tenggara (visi ASEAN-10) telah tercapai (Direktorat Jenderal Kerjasama ASEAN Departemen Luar Negeri Republik Indonesia, 2007:4).

Mantan Sekjen ASEAN, Rodolfo Severino Jr, dalam sebuah pidatonya di Universitas Sydney, Australia tahun 1998 menyatakan ASEAN's founders in 1967 intended ASEAN to be an association of all the states of Southeast Asia cooperating voluntarily for the common good, with peace and economic, social and cultural development its primary purposes. ASEAN is not and was not meant to be a supranational entity acting independently of its members. It has no regional parliament or council of ministers with law-making powers, no power of enforcement, no judicial system.
Apa yang dikemukakan oleh Severino tersebut memang dapat dijustifikasi dengan melihat tujuan ASEAN yang terdapat dalam Deklarasi Bangkok adalah untuk: Pertama, Mempercepat pertumbuhan ekonomi, kemajuan sosial serta pengembangan kebudayaan di kawasan ini melalui usaha bersama dalam semangat kesamaan dan persahabatan untuk memperkokoh landasan sebuah masyarakat bangsabangsa Asia Tenggara yang sejahtera dan damai; Kedua, Meningkatkan perdamaian dan stabilitas regional dengan jalan menghormati keadilan dan tertib hukum di dalam hubungan antara Negara-Negara di kawasan ini serta mematuhi prinsip-prinsip Piagam Perserikatan Bangsa-Bangsa; Ketiga, Meningkatkan kerjasama yang aktif dan saling membantu dalam masalah-masalah yang menjadi kepentingan bersama di bidang-bidang ekonomi, sosial, teknik, ilmu pengetahuan dan administrasi; Keempat, Saling memberikan bantuan dalam bentuk sarana-sarana pelatihan dan penelitian dalam bidang-bidang pendidikan, profesi, teknik dan administrasi; Kelima, Bekerjasama secara lebih efektif guna meningkatkan pemanfaatan pertanian dan industri mereka, memperluas perdagangan dan pengkajian masalah-masalah komoditi internasional, memperbaiki sarana-sarana pengangkutan dan komunikasi, serta meningkatkan taraf hidup rakyat mereka; Keenam, Memajukan pengkajian mengenai Asia Tenggara; Ketujuh, Memelihara kerjasama yang erat dan berguna dengan berbagai organisasi internasional dan regional yang mempunyai tujuan serupa, dan untuk menjajaki segala kemungkinan untuk saling bekerjasama secara erat di antara mereka sendiri (Direktorat Jenderal Kerjasama ASEAN Departemen Luar Negeri Republik Indonesia, 2007:2)

Prinsip utama dalam kerjasama ASEAN antara lain adalah persamaan kedudukan dalam keanggotaan (equality), tanpa mengurangi kedaulatan masing-masing Negara anggota (Huala Adolf, 1990:99-110). NegaraNegara anggota ASEAN sepenuhnya tetap memiliki kedaulatan ke dalam maupun ke luar (sovereignty), sedangkan musyawarah (consensus and consultation), kepentingan bersama (common interrest), dan saling membantu (solidarity) dengan semangat ASEAN merupakan ciri kerjasama ini.

ASEAN dan Negara-Negara anggota akan bertindak sesuai dengan prinsip-prinsip sebagai berikut: 1. Menghormati kemerdekaan, kedaulatan, kesamaan, integritas wilayah nasional, dan identitas nasional setiap Negara; 2. Komitmen bersama dan 
tanggung jawab bersama dalam daerah meningkatkan perdamaian, keamanan dan kemakmuran; 3. Penolakan dari agresi dan ancaman atau menggunakan kekerasan atau tindakan lain dengan cara apa pun tidak konsisten dengan Hukum Internasional; 4. Mengusahakan perdamaian dalam penyelesaian sengketa; 5 . Non intervensi dalam urusan internal Negara-Negara anggota ASEAN; 6. Untuk menghormati hak setiap Negara Anggota untuk memimpin, nasional yang bebas dari keberadaan eksternal gangguan, subversi dan kekerasan; 7. Peningkatan konsultasi mengenai hal-hal serius mempengaruhi minat ASEAN secara umum; 8 . Ketaatan terhadap aturan hukum, tata pemerintahan yang baik, asas demokrasi dan pemerintah yang dijalankan berdasarkan undang-undang; 9. Untuk menghonnati kebebasan fundamental, perkembangan dan perlindungan hak asasi manusia, dan perkembangan keadilan sosial; 10. Menegakkan Piagam PBB dan Hukum Internasional, termasuk hukum kemanusiaan internasional, yang diikuti oleh Anggota perserikatan ASEAN; 11. Penolakan untuk memberikan suara atau melakukan sesuatu dari partisipasi dalam setiap kebijakan atau kegiatan, termasuk penggunaan dan wilayah, diikuti oleh Negara Anggota ASEAN atau non Negara ASEAN atau anggota non Negara yang mengancam kedaulatan, integritas teritorial atau stabilitas politik dan ekonomi negara-negara anggota ASEAN; 12. Menghargai berbagai budaya, bahasa dan agama dari masyarakat ASEAN, sementara menekankan nilainilai umum mereka dalam semangat kesatuan dalam keragaman; 13. Pusat dari ASEAN di luar politik, ekonomi, sosial dan hubungan budaya, sementara sisanya sedang aktif terlibat, melihat bagian yang lain, termasuk juga yang bersifat tidak membedakan; 14. Kepatuhan terhadap peraturan perdagangan multilateral dan aturan dasar rezim ASEAN untuk pelaksanaan yang efektif dari pengurangan kemajuan ke arah penyisihan dari setiap batasan yang menuju kepada penyatuan daerah ekonomi ke dalam pasar perekonomian (Piagam ASEAN).

Preambule pada Deklarasi Bangkok memuat tujuan ASEAN yaitu meletakkan dasar atau fondasi yang kokoh untuk memajukan kerja sama regional, memperkuat stabilitas ekonomi, dan sosial serta memelihara perdamaian dan keamanan di kawasan Asia Tenggara (Faustinus Andrea, 2006:183). Termasuk dalam tujuan tersebut adalah keinginan menyelesaikan sengketa di antara anggotanya secara damai tanpa menggunakan cara-cara kekerasan atau perang.
Salah satu instrumen penting dalam upaya mewujudkan dan menciptakan stabilitas politik dan keamanan di kawasan Asia Tenggara adalah The Treaty of Amity and Cooperation in Southeast Asia 1976 (TAC). Pada dasarnya prinsip-prinsip yang terkandung di dalam TAC juga tercermin di dalam Piagam PBB antara lain prinsip non-interference (non intervensi) dan penggunaan cara-cara damai dalam menyelesaikan sengketa tanpa menggunakan kekerasan yang timbul di antara negara-negara penandatangan TAC.

TAC yang ditandatangani pada pertemuan puncak ASEAN pertama di Bali, pada tanggal 24 Februari 1976 sering disebut sebagai wujud dari nilai-nilai global yang mendasari pembentukan organisasi regional. Dalam pertemuan di Bali tersebut, negaranegara ASEAN sepakat untuk Saling menghormati kemedekaan, kedaulatan, dan integritas wilayah semua bangsa; Setiap negara berhak memelihara keberadaanya dari campur tangan, subversi, kekerasan dari kekuatan luar; Tidak mencampuri urusan dalam negara lain; Menyelesaikan perbedaan pendapat dan pertikaian dengan jalan damai; Menolak ancaman penggunaan kekerasan (Bambang Cipto, 2007:23).

Perkataan intervensi kerapkali dipakai secara umum untuk menunjukkan hampir semua tindakan campur tangan oleh suatu negara dalam urusan negara lain. Non-intervention is a foreign policy which holds that political rulers should avoid alliances with other nations, but still retain diplomacy, and avoid all wars not related to direct self-defense. This is based on the grounds that a state should not interfere in the internal politics of another state, based upon the principles of state sovereignty and self-determination. A similar phrase is strategic independence.

Berdasarkan pengertian yang khusus, intervensi terbatas pada tindakan mencampuri urusan dalam negeri atau luar negeri dari negara lain yang melanggar kemerdekaan negara itu, bukanlah satu intervensi suatu pemberian nasehat oleh suatu negara pada negara lain mengenai beberapa hal yang terletak di dalam kompetensi dari negara yang disebut kemudian untuk mengambil keputusan untuk dirinya, walaupun pada umumnya orang mengangap itu sebagai suatu intervensi (J.G. Starke, 2007:683). Campur tangan harus berbentuk suatu perintah, yaitu bersifat memaksakan atau ancaman kekerasan berdiri di belakangnya, campur tangan itu hampir selalu disertai dengan bentuk atau implikasi tindakan untuk menganggu kemerdekaan politik negara bersangkutan (J.L. Brierly, 1996:26). 
Dari penjelasan tersebut di atas ASEAN sangat mempertegas dirinya yang sebagai suatu organisasi internasional yang terdapat di kawasan Asia Tenggara yang masih saat ini menjunjung tinggi suatu prinsip non intervensi yang diberlakukan kepada kesepuluh negara anggota ASEAN. Tentu hal ini membawa suatu dampak yang positif dan negatif bagi berlangsungnya organisasi internasional ini, banyak para pakar Hukum Internasional khususnya organisasi internasional yang memprediksikan bahwa ASEAN jika dengan tetap dan masih mempertahankan prinsip ini akan berdampak buruk bagi organisasi ini (bubar) akan tetapi justru dengan adanya prinsip non intervensi ini membuat ASEAN dapat bertahan sampai sekarang. Dalam artikel ini kami sebagai penulis ingin meneliti tentang bagaimanakah prinsip non intervensi yang masih melingkar dalam tubuh ASEAN, dapat mempererat hubungan antar anggota sehingga setiap permasalahan yang tengah dihadapi oleh masing-masing anggota ASEAN khususnya tentang HAM, sosial budaya dan lain-lain dapat ikut berpartisipasi untuk menyumbangkan pemikiran dan masukkannya untuk dapat membantu menyelesaikan permasalahan yang tengah dihadapi oleh para anggota tanpa harus melanggar kedaulatan masing-masing negara anggota ASEAN.

\section{RUMUSAN PERMASALAHAN}

Berdasarkan latar belakang di atas, dapat diambil suatu rumusan masalah bagaimanakah prinsip non intervensi yang masih dipegang teguh oleh ASEAN dapat memberikan kontribusi yang postif bagi negara negara anggota ASEAN di dalam menjalankan hubungan kerjasama satu negara dengan negara yang lain.

\section{METODE PENELITIAN}

Penelitian diartikan sebagai serangkaian kegiatan yang teratur yang membantu pengembangan ilmu lain dalam mengungkapkan suatu kebenaran, dapat dikatakan sebagai suatu proses, serangkaian kegiatan yang menimbulkan suatu akibat. Rangkaian kegiatan itu berupa penetapan permasalahan yang hendak diteliti, pengumpulan data yang diperlukan untuk menelaah permasalahan yang ditetapkan, mengolah data yang telah dikumpulkan, dan menarik kesimpulan berdasarkan pengolahan data tersebut, adapun akibat yang ditimbulkannya adalah pengungkapan suatu kebenaran (F. Sugeng Istanto, 2007:3).

Penulisan ini bersifat deskriptif yaitu penulisan yang dimaksud untuk memberikan gambaran yang jelas mengenai Meneropong Prinsip Non intervensi Yang Masih Melingkar Dalam ASEAN. Penulisan artikel ini adalah penelitian hukum normatif, yang datanya diperoleh melalui studi dokumen atau kepustakaan yang dilakukan dengan cara meneliti bahan-bahan kepustakaan seperti buku, majalah, perjanjian internasional (Piagam ASEAN), makalah-makalah, jurnal, artikel-artikel, surat kabar serta situs-situs internet yang berkaitan dengan objek yang ditulis.

\section{PEMBAHASAN}

\section{Kedaulatan Suatu Negara}

Jean Bodin mengatakan bahwa kedaulatan sebagai atribut negara, sebagai ciri khusus dari negara. Kedaulatan merupakan kekuasaan mutlak dan abadi dari negara yang tidak terbatas dan tidak dapat dibagibagi. Selanjutnya, Jean Bodin menyatakan bahwa tidak ada kekuasaan lain yang lebih tinggi yang dapat membatasai kekuasaan negara. Menurutnya, yang dinamakan kedaulatan mengandung satu-satunya kekuasaan sebagai: Asli, artinya tidak diturunkan dari suatu kekuasaan lain; Tertinggi, tidak ada kekuasaan lain yang lebih tinggi yang dapat membatasi kekuasaannya; Bersifat abadi dan kekal; Tidak dapat dibagi-bagi karena hanya ada satu kekuasaan tertinggi (F.X. Adji Samekto, 2009:49).

Apabila pijakan pikir kita mengenai kedaulatan berangkat dari ajaran klasik Jean Bodin, dimilikinya kekuasaan tertinggi oleh negara ini memang dapat bertentangan dengan Hukum Internasional sebagai kaidah-kaidah atau norma-norma yang mengatur hubungan-hubungan negara. Dalam hal ini Hukum Internasional menjadi tidak berlaku karena negara memiliki kekuasaan tertinggi dan tidak mau mengakui adanya kekuasaan yang lebih tinggi daripada kekuasaan negara. Akibatnya, Hukum Internasional tidak akan dapat menjadi sarana hubungan antar negara karena masing-masing negara dalam hubungan internasional masih menonjolkan kedaulatannya.

Eksistensi kedaulatan dalam Hukum Internasional pada saat ini ialah dimana kenyataan masyarakat internasional dewasa ini merupakan suatu masyarakat yang terdiri atas negara-negara yang bebas, merdeka, dan sederajat. Sekalipun masing-masing negara memiliki kekuasaan tertinggi yang disebut dengan kedaulatan, kenyataannya di dalam masyarakat internasional telah muncul hubungan yang tertib. Satjipto Raharjo menguraikan bahwa ketertiban tampil sebagai unsur pertama yang membentuk suatu sistem 
sosial (sistem sosial dapat dijelaskan sebagai cara mengorganisasi kehidupan dalam suatu komunitas tertentu). Timbulnya ketertiban disebabkan anggota masyarakat itu masing-masing untuk dirinya sendiri dan dalam berhadapan dengan anggota yang lain mengetahui apa yang seharusnya dilakukan (Satjipto Rahardjo, 1980:29). Guna memelihara sistem sosial yang sudah berjalan karena adanya ketertiban itu, maka diperlukan mekanisme pengendalian sosial karena tidak semua anggota masyarakat selalu bersedia untuk menundukkan diri pada petunjuk atau norma yang telah ditentukan (Satjipto Rahardjo, 1980:32).

Mekanisme ini juga berlaku dalam komunitas internasional, maka dari itu, harus dikatakan bahwa ketertiban dalam masyarakat internasional akan dapat terpelihara selama mereka mengetahui tentang apa yang boleh dan tidak boleh dilakukan dalam hubungan internasional. Sudah barang tentu untuk memelihara ketertiban dalam hubungan internaisonal ini dibutuhkan petunjuk-petunjuk ataupun sanksi sebagai mekanisme pengendalian sosial. Sistem petunjuk-petunjuk dan sanksi inilah yang, antara lain, dikemas dalam aturanaturan Hukum Internasional. Menurut Mochtar Kusumaatmadja (1982:19), tunduknya suatu negara pada kebutuhan pergaulan masyarakat internasional merupakan syarat mutlak bagi terciptanya suatu masyarakat internasional yang teratur. Terciptanya suatu masyarakat yang teratur demikian hanya mungkin terwujud dengan adanya Hukum Internasional.

\section{Prinsip Non Intervensi yang Melingkar dalam ASEAN}

Salah satu faktor terjaganya perdamaiaan dunia seusai Perang Dunia II adalah prinsip non intervensi yang tercantum dalam Piagam PBB dan Dasasila Bandung, yang merupakan keputusan terpenting Konferensi Asia Afrika di Bandung tahun 1955. Berdirinya PBB disponsori oleh lima negara pemenang Perang Dunia II, yakni AS, Inggris, Prancis, China, dan Uni Soviet. Suatu negara atau kekuatan apa pun dari luar tidak boleh melakukan intervensi, baik politik apalagi militer terhadap suatu negara yang sedang menghadapi masalah atau kemelut di dalam negerinya. Namun dalam kenyataan, setelah berakhirnya perang dingin prinsip non intervensi ini mulai dilanggar, terutama oleh pihak Barat dengan berbagai dalih (Pramudito, www.beritasatu.com).

Dari prinsip-prinsip utama dalam ASEAN terkait dengan prinsip non intervensi dalam Hukum
Internasional. Prinsip kedaulatan negara dan prinsip non intervensi diatur dalam Piagam PBB Pasal 2 ayat (1) yang menyatakan The organization is based on the principle of the sovereign equality of all the members. Sedangkan pada Pasal 2 ayat (4) All members shall refrain in their international relation from the threat or use of force against the teritorial integrity or political independence of any state, or in any other manner in consistent with the purpose of the United Nations. Dan Pasal 2 ayat (7) Nothing contained in the present charter shall autorize the United Nations to intervene in matters which essentially within the domestic jurisdiction of any state or shall require the Members to submit such matters to settlement under the present charter, but the principle shall not prejudice the application of enforc ement measures under chapter VII.

Ketentuan piagam PBB tersebut dengan jelas menyatakan bahwa dalam hubungan antar negara tidak diperbolehkan adanya intervensi. Pengaturan tersebut semakin dikuatkan dengan Resolusi Majelis Umum PBB Nomor 2625 (XXV) yang dikeluarkan tanggal 24 Oktober 1970, yang kemudian diterima sebagai Deklarasi Majelis Umum tentang PrinsipPrinsip Hukum International Mengenai Hubungan Persahabatan dan Kerjasama antar Negara yang Berkaitan dengan Piagam PBB. Dalam praktek negara-negara dewasa ini, prinsip-prinsip tersebut kerap dilanggar dengan alasan-alasan kemanusiaan. Intervensi kemanusiaan di Irak tahun 1991, Somalia tahun 1992 dan Kosovo tahun 1999 dapat dijadikan bukti bahwa doktrin tersebut telah dilakukan oleh negara-negara dalam hubungan internasionalnya intervensi kemanusiaan mendapatkan legitimasinya menurut para pendukungnya berdasarkan penafsiran atas Pasal 2 ayat (4) Piagam PBB.

Pasal 2 ayat (4) bukanlah sebuah larangan yang absolut, melainkan sebuah batasan agar sebuah intervensi tidak melanggar kesatuan wilayah (territorial integrity), kebebasan politik (political independence) dan tidak bertentangan dengan tujuan PBB (in any other manner inconsistent with the Purposes of the United Nations). Kesatuan wilayah dimaksudkan jika sebuah negara kehilangan wilayahnya secara permanen sedangkan dalam intervensi kemanusian pihak yang melakukan intervensi tidak mengambil wilayah negara secara permanen, tindakan tersebut hanya untuk memulihkan hak asasi manusia (Anthony D’Amato, 2001:20) 
Intervensi terhadap kemanusiaan tidak melanggar kebebasan politik sebuah negara. Tindakan tersebut hanya bertujuan untuk memulihkan hak asasi manusia pada suatu negara. Setiap negara dan penduduknya tetap memiliki kebebasan politik. Atas asumsi ini intervensi kemanusiaan tidak melanggar piagam PBB. Hal yang sama juga dikemukakan oleh Teson (Eric Adjie, 2005:29), menurut beliau kekerasan bersenjata hanya dilarang oleh PBB jika melanggar: when it impairs the territorial integrity of the target state; when it affects its political independence; or when it is otherwise against the purposes of the United Nations.

Intervensi kemanusiaan dapat dikatakan sah apabila tidak melanggar batasan yang ditentukan oleh ketentuan Pasal 2 ayat (4). Legalitas intervensi kemanusiaan kemudian juga dihubungkan dengan tujuan PBB untuk menghormati hak asasi manusia (Pasal 1 ayat (3) Piagam PBB). Menurut D'Amato, sejak tahun 1945 dan lahirnya konvensi tentang pelarangan genosida, deklarasi HAM universal, maka kewenangan negara untuk bertindak sewenang-wenang atas warganya telah dibatasi. Batas teritorial sudah tidak menjadi permasalahan dalam pelaksanaan dan perlindungan HAM.

Kedaulatan negara yang biasanya menjadi alasan bahwa intervensi kemanusiaan tidak dapat dibenarkan berdasarkan Hukum Internasional secara kontekstual telah gagal. Pendapat ini diberikan oleh Hans Kelsen (2007:414-415), menurut beliau, bahwa tujuan adanya Hukum Internasional adalah untuk membatasi kedaulatan negara itu sendiri. Sejak individu menjadi subyek Hukum Internasional, maka sebenarnya kedaulatan negara itu diperoleh dari individu yang mendelegasikan kewenangannya kepada negara. Jadi, ketika negara telah melanggar hak-hak individu, maka para individu tersebut dapat meminta bantuan kepada pihak lain (negara) untuk memulihkan hakhak mereka. Pada saat itulah intervensi kemanusiaan menjadi eksis dan timbul kewajiban negara untuk melakukan kerjasama (bantuan) antara mereka untuk melindungi dan mempromosikan hak asasi manusia. Praktik-praktik negara saat ini juga telah menimbulkan sebuah preseden, bahwa intervensi kemanusiaan dapat dianggap sebagai kebiasaan internasional. Intervensi kemanusiaan merupakan sebuah kewajiban tiap-tiap negara. Doktrin tersebut bukan merupakan hak seperti hak membela diri. Doktrin tersebut menjadi eksis ketika terjadi sebuah pelanggaran terhadap hak asasi manusia. Intervensi tersebut dapat dilakukan baik secara individual maupun kolektif.

Prinsip non intervensi selama ini dipegang teguh oleh para anggota ASEAN dalam kebijakan regionalnya, di samping prinsip-prinsip lain seperti saling menghormati, konsensus, dialog dan konsultasi. Prinsip non intervensi yang selama ini dijunjung tinggi telah banyak memberi kontribusi terhadap eksistensi ASEAN. Pada tingkat yang paling dasar, prinsip ini merupakan wujud nyata penghormatan terhadap kedaulatan masing-masing negara anggota. Hal ini amat penting, mengingat sejarah menjelang pembentukan ASEAN yang diwarnai sejumlah konflik antar negara bakal calon anggota ketika itu seperti disebutkan di atas (Adityo Budiatno, http://adityobu diatno.blogspot.com/2010/03/prinsip-nonintervensidan-prospek.html).

Jaminan pengakuan kedaulatan ini menjadi faktor penting terhadap meredamnya sikap saling curiga sesama negara anggota ASEAN. Hilangnya sisa-sisa kecurigaan ini selanjutnya membantu tumbuhnya saling percaya yang cukup tinggi antara anggota ASEAN. Hal ini penting, sebab rasa percaya timbal balik menjadi prasyarat eksisnya suatu organisasi regional beranggotakan negara dengan perbedaan kepentingan yang tak terelakkan. Prinsip ini juga telah berfungsi sebagai mekanisme preventif terhadap munculnya sejumlah konflik terbuka di antara negara anggota ASEAN. Penghormatan terhadap apa yang dianggap menjadi urusan dalam negeri negara anggota lain secara tidak langsung ikut mencegah terjadinya salah persepsi antaranggota. Prinsip non intervensi ini telah memberikan sumbangan yang teramat berarti dalam pengembangan ASEAN sejak berdirinya hingga saat ini.

Seiring dengan perkembangan konstelasi politik global, nampaknya prinsip ini mulai harus ditinggalkan oleh ASEAN. Karena dalam Piagam ASEAN disebutkan bahwa tujuan ASEAN ke depan adalah maintain and enhance peace, security and stability and further strengthen peace-oriented values in the region, serta to enhance regional resilience by promoting greater political, security, economic and socio-cultural cooperation. Pernyataan ini menunjukkan bahwa ASEAN ke depan merupakan suatu entitas yang satu, ini diperkuat dengan jargon ASEAN, One Vision, One Identity, One Community. (http://skiasyik.wordpress.com/2008/03/25/aseancharter/ -_ftn3). 
Namun dalam kenyataannya nampaknya prinsip ini belum mau ditinggalkan oleh ASEAN, terlihat dari Pasal 2 Piagam ASEAN, yaitu menghormati kedaulatan, persamaan, integritas teritorial, identitas nasional; tidak mencampuri urusan dalam negeri anggota ASEAN; menghargai hak anggota untuk mempertahankan integritas nasional yang bebas dari pengaruh asing serta subversi dan koersi; tidak mencampuri dalam kegiatan yang akan berdampak pada kedaulatan dan integritas teritorial negara anggota lainnya; termasuk tidak menggunakan daerahnya untuk kegiatan tersebut; penghargaan terhadap kebebasan fundamental serta promosi dan perlindungan HAM serta keadilan sosial.

Dalam berbagai peraturan yang disebut di atas nampak bahwa ASEAN belum akan meninggalkan prinsip non intervensi sebagai prinsip dasarnya. Oleh karena itu, ASEAN tidak dapat mengintervensi pelanggaran-pelanggaran yang terdapat atau yang terjadi di dalam organisasi ini, misalnya pelanggaran HAM yang dilakukan oleh para anggota-anggotanya dan yang terjadi dalam negara anggota ASEAN. Sebagai contoh kasus, isu Myanmar telah memunculkan perbedaan pandangan dan sikap di kalangan negara anggota ASEAN mengenai cara-cara menangani kasus Myanmar maupun mengenai implikasi dari kasus tersebut terhadap kerja sama ASEAN di masa mendatang. ASEAN seolah-olah tidak pernah bebas dari persoalan Myanmar (Antarto Bandoro, The Jakarta Post, 2003) khususnya ketika ASEAN berbicara mengenai bagaimana membangun kawasan Asia Tenggara yang lebih demokratis. Isu Myanmar hampir tidak pernah absen dari agenda pertemuan intern para Menteri Luar Negeri ASEAN dan antara ASEAN dan mitra dialognya, karena desakan Amerika Serikat isu Myanmar bahkan nyaris dibahas dalam forum PBB, ketika Amerika Serikat melihat prospek yang tidak cerah dari demokratisasi di Myanmar (Anonim, 2007, US Wanst Myanmar on UN Agenda, http://english.aljazeera.net)

Myanmar masih menyisakan permasalahan yang sangat penting dan mendasar yang kembali membawa Myanmar ke jurang yang sama tentang permasalahan HAM yaitu terdapat indikasi pemerintah Myanmar (masih) melakukan pelanggaran HAM pada etnis Rohingya. Sejarah masih mencatat pada saat bebasnya penerima nobel perdamaian Aung San Suu Kyi dan masuknya Aung San Suu Kyi dalam parlemen Myanmar membangkitkan harapan bagi warga minoritas
Rohingya yang terus tertindas. Mereka berharap Suu Kyi akan lantang berbicara terhadap hak-hak kaum Rohingya, sebuah kaum yang disebut PBB sebagai kaum minoritas paling teraniaya di dunia. Namun apa yang terjadi, Suu Kyi masih menghindari isu tersebut. Seperti yang terjadi kala Suu Kyi berbicara di Jenewa, Suu Kyi terlihat seperti tidak ada suatu permasalahan yang besar dengan tidak ingin menyinggung rezim Myanmar (Dewa Gede Sudika Mangku, 2012).

Etnis Rohingya adalah kelompok etnis yang berasal dari Bangladesh, namun telah bermukim di negara bagian Rakhaing di Myanmar sejak abad ke-7 Masehi. Meskipun telah berabad-abad tinggal di Myanmar, pemerintah Myanmar menganggap bahwa Rohingya termasuk dalam etnis Bengali sehingga tidak dapat diakui sebagai salah satu etnis Myanmar. Hilangnya kewarganegaraan membuat etnis Rohingya tidak mendapat perlindungan nasional. Etnis Rohingya mengalami berbagai pelanggaran hak asasi manusia, baik dalam hal berkewarganegaraan hingga dalam hal beragama. Pelanggaran HAM inilah yang mendorong etnis Rohingya untuk meninggalkan Myanmar dan mencari perlindungan di negara lain, beberapa dari mereka pun sampai di Indonesia (Dita Liliansa, 2013).

Masalahnya ada pada prinsip non-interference di ASEAN. Prinsip itu sudah dilegalisasi dan ada di Piagam ASEAN. ASEAN harus bersikap tegas dengan Myanmar. ASEAN bisa mengatakan ke Myanmar, jangan macam-macam dengan isu ini karena setiap pengungsi Myanmar pergi ke negara ASEAN dan impact (akibat) dari masuknya pengungsi itu dapat menyebab instabilitas dan gangguan keamanan di negara yang bersangkutan. Negara-negara seperti Vietnam dan Singapura juga pasti menolak intervensi terhadap Myanmar. Mereka akan menganggap hal-hal seperti itu adalah urusan dalam negeri Myanmar. Sebenarnya, isu ini tidak bisa disepelekan, karena ASEAN juga memiliki kewajiban untuk melindungi masyarakat sipil ASEAN. Indonesia pun ikut dikritik ketika mereka membicarakan Rohingya, tapi mereka tidak pernah membahas Ahmadiyah. Thailand memiliki cerita lain di dalam negerinya yang sampai sekarang masing bergejolak. Demokrasi menjadi suatu momok yang masih menghantui Thailand sampai saat ini, menjadi negara anggota ASEAN yang tidak pernah dijajah oleh bangsa lain atau negara lain, menjadikan Thailand menjadi suatu bangsa yang berdiri tanpa ada penuntunnya. Dari kasus Thaksi hingga pemilu 
yang selalu mendatangkan suatu permasalahan yang kompleks, membuat sebagian negara anggota lain serta masyarakat internasional berpikir ini merupakan masalah klasik yang dimiliki oleh Thailand dan yang dapat menyelesaikan persoalan ini adalah negera itu sendiri, lantas untuk apa Thailand bergabung dengan menjadi anggota ASEAN jika beban tersebut harus dipanggul sendirian tanpa meminta bantuan dari negara lain untuk membantu menyelesaikan dalam negerinya tersebut.

Misalnya meminta pendapat Indonesia tentang bagaimana suatu negara demokrasi tersebut, sebaliknya jika negara-negara anggota ASEAN yang lainnya mengulurkan tangan untuk memberikan bantuan tentu hal ini sangat susah untuk bisa tercapai dan terwujud. Alasannya sederhana karena di ASEAN masih memegang teguh dan selalu mengedepankan prinsip non intervensi, hal ini yang menjadi tembok besar bagi setiap negara-negara anggota ASEAN jika ingin melakukan atau memberikan suatu bantuannya.

Berdasarkan pemaparan kasus di atas, ASEAN telah berinisiatif untuk membentuk dan membuat Badan HAM ASEAN yang dibentuk berdasarkan Piagam ASEAN Pasal 14 ayat 1 yang menyatakan in conformity with the purpose and principles of the Piagam ASEAN relating to the promotion and protection of human rights and fundamental freedoms, ASEAN shall establish an ASEAN Human Rights Body, akan tidak dapat menjalankan fungsinya secara maksimal. Karena seharusnya Badan HAM ASEAN mampu bertindak untuk menyelesaikan pelanggaran HAM yang terjadi dengan masuk ke negara yang melanggar HAM tersebut dan mengintervensi tindakan yang dilakukan. Sehingga Badan HAM ASEAN ini hanya dapat bertindak dalam lingkup pertemuan menteri luar negeri ASEAN seperti dinyatakan dalam Pasal 14 ayat 2, This ASEAN Human Rights Body shall operate in accordance with the terms of reference to be determined. Secara filosofis dengan dibentuknya Badan HAM ASEAN ini, negara anggota akan lebih memilih penyelesaian regional daripada internasional. Penyelesaian regional dipilih karena aturan-aturan disesuaikan dengan kondisi kawasan. Badan HAM ASEAN ini membutuhkan landasan dan kedudukan yang kuat untuk dapat memberikan teguran. Muncul pertanyaan, apakah ruang lingkup kewenangan dan tugasnya mampu menyelesaikan perkara-perkara pelanggaran HAM yang dilakukan oleh negaranegara anggota ASEAN, sementara prinsip dasar dalam Piagam ASEAN adalah menghormati asas integritas teritorial, kedaulatan, non intervensi dan jatidiri nasional anggota ASEAN.

Keinginan organisasi ASEAN untuk menjadi One Community nampaknya akan terhambat karena prinsip ini. Berdasarkan pada konsep integrasi yang diutarakan di atas, kalau ingin mengintegrasikan diri menjadi sesuatu yang lebih besar berarti harus memindahkan kesetiaan yang ada, atau paling tidak mengurangi kedaulatan negara dan memindahkannya ke cakupan yang lebih luas, dalam konteks ini berarti negara-negara anggota ASEAN memindahkan atau mengurangi sedikit kedaulatannya untuk membangun suatu integrasi ASEAN yang lebih bersatu, sehingga One Vision, One Identity, One Community dapat terwujud (Hiro Katsumata, 2004:237).

Sejak berdirinya ASEAN organisasi ini telah memutuskan untuk bekerjasama secara komprehensif di bidang keamanan, ekonomi, dan sosial budaya. Dalam perkembangannya, kerjasama ASEAN lebih banyak dilakukan di bidang ekonomi, sementara kerjasama di bidang politik-keamanan masih belum maksimal akibat adanya persepsi ancaman yang berbeda-beda dan penerapan prinsip-prinsip non intervensi (non interference) serta sovereign equality oleh negaranegara anggota ASEAN.

Komunitas keamanan ditujukan untuk dapat mempercepat kerjasama politik keamanan di ASEAN untuk mewujudkan perdamaian di kawasan termasuk dengan masyarakat internasional. Komunitas Keamanan ASEAN bersifat terbuka, berdasarkan pendekatan keamanan komprehensif, dan tidak ditujukan untuk membentuk suatu pakta pertahanan atau aliansi militer, maupun kebijakan luar negeri bersama (common foreign policy). ASEAN Security Community (ASC) juga mengacu kepada berbagai instrumen politik ASEAN yang telah ada seperti ZOPFAN, TAC, dan Treaty on Southeast Asia Nuclear Weapon-Free Zone (SEANWFZ) selain menaati Piagam PBB dan prinsipprinsip Hukum Internasional terkait lainnya (D.G.E. Hall, 1981:567-612).

Komunitas Keamanan merupakan sebuah pilar yang fundamental dari komitmen ASEAN dalam mewujudkan Komunitas ASEAN. Pembentukan Komunitas Keamanan ASEAN akan memperkuat ketahanan kawasan dan mendukung penyelesaian sengketa secara damai. Terciptanya perdamaian dan stabilitas di kawasan akan menjadi modal bagi proses pembangunan ekonomi dan sosial budaya masyarakat 
ASEAN. Sebagaimana ditegaskan dalam Vientiane Action Programme (selanjutnya dalam penelitian ini disingkat menjadi VAP), Komunitas Keamanan ASEAN menganut prinsip keamanan komprehensif yang mengakui saling keterkaitan antar aspek-aspek politik, ekonomi, dan sosial budaya.

Adapun kerangka ASC meliputi 12 (dua belas) poin sebagai berikut: (CPT. Luhulima, dkk, 2008: 92-94).

Pertama, ASC ditujukan untuk membawa kerja sama politik dan keamanan ASEAN ke tingkat yang lebih tinggi guna menjamin agar negara-negara di kawasan ini hidup dengan damai satu sama lain dan dengan dunia luar dalam lingkungan yang adil, demokratis dan harmonis. Anggota ASC sematamata akan mengandalkan pada proses damai dalam menyelesaikan pertikaian dan sengketa intra-regional, serta memandang keamanan mereka sebagai terkait satu sama lain secara fundamental dan diikat oleh lokasi geografis, visi, dan tujuan yang sama;

Kedua, ASC, sementara mengakui hak berdaulat setiap negara anggota untuk mengikuti kebijakan luar negeri dan pengaturan pertahanan masing-masing dan memperhatikan saling keterkaitan antara realitas politik, ekonomi dan sosial, mengedepankan prinsip keamanan komprehensif yang memiliki aspek politik, ekonomi, sosial dan keamanan yang luas sesuai dengan ASEAN Vision 2020 dari pada suatu pakta pertahanan, aliansi militer atau kebijakan luar negeri bersama;

Ketiga, ASEAN akan terus memajukan solidaritas dan kerja sama regional. Negara-negara anggota akan melaksanakan hak mereka untuk menjalani kehidupan nasional bebas dari campur tangan luar pada masalah dalam negeri masing-masing;

Keempat, ASC akan mematuhi Piagam PBB dan prinsip-prinsip Hukum Internasional lainnya dan menjunjung prinsip-prinsip ASEAN yakni tidak saling mencampuri urusan dalam negeri masing-masing, pembuatan keputusan melalui konsensus, ketahanan nasional, dan regional, penghormatan terhadap kedaulatan nasional dan regional, penghormatan terhadap kedaulatan nasional, penolakan terhadap ancaman dan penggunaan kekerasan, dan penyelesaian perbedaan dan persengketaan secara damai;

Kelima, Isu dan masalah maritim bersifat lintas batas, dan oleh karenanya akan ditangani secara holistis, terintegrasi dan komprehensif. Kerjasama maritim di antara dan sesama anggota ASEAN akan memberikan sumbangan terhadap evolusi ASC;
Keenam, Instrumen-instrumen politik ASEAN yang ada seperti Deklarasi ZOPFAN, TAC, dan SEANWFZ akan tetap memainkan peran penting dalam memajukan rasa saling percaya (Confidence Building Measures/CBM), Preventive Diplomacy dan pendekatan penyelesaian konflik;

Ketujuh, High Council dari TAC akan merupakan komponen penting tersebut dalam ASC mengingat ia merefleksikan komitmen ASEAN untuk mengakhiri perbedaan, pertikaian, dan sengketa secara damai;

Kedelapan, ASC akan menyumbang terhadap pemajuan perdamaian dan keamanan di wilayah Asia Pasifik yang lebih luas dan merupakan refleksi dari kemauan ASEAN untuk melangkah dengan kecepatan yang nyaman untuk semua. Dalam hal ini ARF (ASEAN Regional Forum) akan tetap menjadi forum utama untuk dialog keamanan regional, dengan ASEAN sebagai motor utamanya;

Kesembilan, ASC bersifat terbuka dan berorientasi ke luar dengan menjalin hubungan secara aktif dengan para sahabat dan Mitra Dialog ASEAN dalam rangka memajukan perdamaian dan stabilitas di kawasan ini, dan akan menjadikan ARF sebagai pijakan untuk memfasilitasi konsultasi dan kerja sama antara ASEAN dan sahabat serta para mitra kerja sama antara ASEAN dan sahabat serta para mitra mengenai masalah keamanan regional;

Kesepuluh, ASC akan memanfaatkan sepenuhnya institusi dan mekanisme dalam ASEAN dengan tujuan memperkuat kapasitas nasional dan regional untuk mengatasi terorisme, perdagangan obat-obatan terlarang, perdagangan manusia dan kejahatan transnasional lainnya, dan akan berupaya agar Asia Tenggara tetap bebas dari senjata pemusnah massal. Hal ini akan memungkinkan ASEAN untuk menunjukkan kapasitas dan tanggung jawab yang lebih besar sebagai motor utama ARF;

Kesebelas, ASC akan menjajaki peningkatan kerja sama dengan PBB serta badan-badan internasional dan regional lainnya dalam rangka memelihara perdamaian dan keamanan internasional;

Keduabelas, ASEAN akan mencari cara-cara yang inovatif untuk meningkatkan keamanan dan membangun modalitas ASC, meliputi antara lain elemen-elemen berikut ini: pembentukan norma-norma, pencegahan konflik, pendekatan penyelesaian konflik, dan pembangunan damai pasca-konflik.

Kalau dicermati, kerangka ASC sesungguhnya tidak beranjak jauh dari apa yang sudah dimiliki dan 
dipraktikkan ASEAN selama ini. Prinsip-prinsip mengenai kedaulatan negara, non-intervensi, dan penyelesaian sengketa secara damai tetap menjadi ciri utama ASC. ASC juga menegaskan kembali komitmen terhadap semua instrumen politik ASEAN yang sudah ada. Di samping itu ASC juga menolak pakta militer dan lebih mengedepankan pendekatan keamanan yang komprehensif.

Pencapaian ASC melalui Rencana Aksi yang termuat dalam VAP diwujudkan melalui sejumlah komponen yang terdiri dari political development, sharing and shaping of norms, conflict prevention, conflict resolution, dan post-conflict peace building. Implementasi Rencana Aksi Komunitas Keamanan ASEAN di dalam komponen shaping and sharing of norms ditandai terutama dengan upaya perumusan Piagam ASEAN. Sesuai dengan Cebu Declaration on the Blueprint of the ASEAN Charter yang disahkan pada KTT ASEAN ke-12.

Piagam ASEAN akan mengubah ASEAN sebagai suatu rule based organization hal ini dibutuhkan mengingat selama ini, karakter ASEAN sebagai sebuah asosiasi yang bersifat longgar tidak lagi dirasakan cukup mengakomodasi potensi kerjasama dan menanggapi tantangan integrasi kawasan dan globalisasi. Piagam ASEAN akan merefleksikan perwujudan Komunitas ASEAN yang tidak berupa lembaga supranasional seperti Uni Eropa. Piagam ASEAN tidak dimaksudkan untuk menjadi landasan pembentukan suatu pakta pertahanan, aliansi militer, ataupun kebijakan luar negeri bersama. ASEAN berkomitmen untuk menghasilkan suatu piagam yang bold dan visioner serta mampu mengakomodasi kepentingan perwujudan Komunitas ASEAN.

ASC harus dipakai untuk dijadikan mekanisme untuk memecahkan masalah secara internal yang berpotensi mengganggu stabilitas dan keamanan kawasan melalui cara-cara damai. Termasuk isuisu sensitif yang berpotensi menimbulkan masalah tanpa harus meninggalkan prinsip tidak mencampuri urusan negara lain. Akhirnya, kerjasama keamanan dapat berjalan paralel dengan ekonomi dan sosial budaya sehingga dapat menjadi pijakan yang saling memperkuat. Maka, entitas ASEAN sebagai organisasi regional tetap relevan dan dapat menjadi identitas kolektif yang solid di masa datang (Faustinus Andrea, 2007, http://www.kompas.com).

Hal ini yang hingga saat ini menjadi momok dalam tubuh ASEAN, dimana tidak relanya masing-masing negara anggota ASEAN untuk mengorbankan sedikit kedaulatannya demi kepentingan yang lebih besar dan memperlonggar prinsip non intervensi yang telah dipelihara sejak berdirinya organisasi internasional ini. Jika kita kembali ke pengertian awal bahwa kedaulatan merupakan suatu yang tidak dapat diganggu-gugat oleh setiap negara lain dan kekuasaan yang tidak dapat dibagi-bagi oleh siapa pun dan jika dikaitkan dengan pondasi awal untuk mendirikan organisasi internasional ASEAN ini ialah untuk memperat jalinan kerjasama antar kawasan Asia Tenggara, tentu hal ini masih berjalan sendiri-sendiri, jika kita lihat dalam hal penanganan sengketa-sengketa internasional yang melibatkan negara-negara annggota ASEAN, kemudian pelanggaran hak-hak asasi manusia, dan gejolak politik dalam negeri yang makin tidak dapat di kontrol oleh masing-masing negara yang bertikai.

Dengan melihat kejadian dan pelanggaranpelanggaran kemanusiaan, pembantaian dimanamana bahkan terjadi pembunuhan, selanjutnya di salah satu negara anggota ASEAN akan menuju perang saudara. Apakah para pemimpin ASEAN dengan melihat kejadian ini akan menjadi penonton setia dan selalu berpegangan teguh kepada prinsip non intervensi yang dijunjung tinggi tersebut. Sudah saatnya prinsip itu diberikan suatu kelonggoran dan fleksibelitas di dalam menjalankannya khusunya di dalam dan bidang kemanusian, dan sudah sepantas dan sepatutnya masing-masing negara anggota ASEAN berpikir untuk melakukan terobosan ini tentu hal ini akan sangat baik untuk perkembangan ASEAN ke depannya dan akan sangat dewasa dalam menyikapi setiap permasalahan yang terjadi di dalam suatu kawasan Asia Tenggara tujuannya ialah untuk menciptakan suatu One Community di ASEAN.

Banyak kalangan menyatakan bahwa prinsip non intervensi membawa angin segar bagi perkembangan ASEAN sampai sejauh ini, akan tetapi dampak yang kurang baik justru lahir juga, jika ASEAN terus memegang prinsip ini. Kenapa kami katakan kurang baik, hal ini dikarenakan prinsip non intervensi jika masih melingkar dalam tubuh ASEAN dampaknya adalah tidak akan membuat kesepuluh negara anggota ASEAN tumbuh menjadi anggota yang dewasa di dalam penanganan setiap kasus-kasus atau pelanggarapelanggaran yang terjadi diantara para anggotanya. Jika masih berlindung dalam kedok dan tameng prinsip non intervensi ini, setiap permasalahan yang terdapat di dalam anggota ASEAN akan diselesaikan sendiri 
(jika mereka bisa dan dapat menyelesaikannya) jika sebaliknya mereka tidak dapat menyelesaikannya, menjadi suatu permasalahan yang berlarut-larut dan akan menjadi sorotan dunia internasional dan menyebut ASEAN adalah sekumpulan suatu negaranegara sekawasan saja tanpa ada yang mampu menolong satu sama lainnya.

Pelanggaran HAM yang terjadi di Thailand para biksu dianiaya dan bahkan ada yang dibunuh, kemudian kita lihat kejadian pelanggaran HAM di Myanmar, dan sengketa yang melibatkan negara-negara anggota ASEAN, seperti yang sudah kita ketahui bersama bahwa ASEAN telah memiliki suatu sistem penyelesaian sengketa yang telah diatur di dalam Piagam ASEAN dan Treaty of Amity and Cooperation in Southeast Asia 1976 (TAC), akan tetapi para pihak yang sedang bersengketa lebih nyaman membawa sengketa mereka kehadapan Mahkamah Interasional (MI). Jika kita menelisik kasus tersebut dan memahami lebih dalam, ada suatu keengganan bagi para negara yang sedang menghadapi masalah dalam negeri maupun sengketa antar negara anggota untuk meminta bantuan sesama negara anggota ASEAN lainnya, tentu saja dengan dalil bahwa mereka masih dapat menyelesaikan permasalahannya dalam negerinya.

\section{PENUTUP}

\section{Kesimpulan}

Kasus pelanggaran HAM di wilayah Asia Tenggara sudah sepatutnya para pemimpin di ASEAN memikirkan suatu kelonggaran atau fleksibelitas untuk memandang atau menerapkan dan menjalankan prinsip ini, tidak kaku seperti di awal pembentukan ASEAN. Setidaknya memberikan ruang gerak bagi penegak hukum khususnya bidang HAM untuk memberikan rekomendasi atau masukkan bahwa apa yang dilakukan oleh suatu negara anggota ASEAN telah menyimpang dari prinsip-prinsip kemanusiaan dunia internasional. Dengan begitu memberikan efek jera bagi setiap negara anggota yang semena-mena terhadap pelanggaran kemanusiaan dan hal ini sudah menjadi suatu bagian yang harus dilakukan oleh setiap suatu negara di dunia internasional khususnya dalam hubungan internasional dan Hukum Internasional.

\section{Rekomendasi}

Sejarah terbentuknya ASEAN prinsip nonintervensi sangat memiliki peran yang sangat luar biasa dalam menjaga keutuhan di masing-masing negara anggota. Akan tetapi hal ini harus dipikirkan oleh para pemegang kekuasaan masing-masing negara anggota untuk memikirkan lebih lanjut tentang prinsip yang dikenal kaku ini. Misalnya disaat negara anggota dilanda permasalahan kemanusiaan dan pelanggaran HAM seharusnya prinsip non intervensi tidak dikedepankan akan tetapi prinsip kemanusiaan yang lebih diutamakan tentu hal ini bertujuan untuk menciptakan suatu demokratisasi di setiap negara anggota ASEAN yang sedang dilanda musibah dan hal ini sesuai dengan cita-cita yang telah dituangkan dalam Deklarasi Bangkok maupun Piagam ASEAN.

\section{DAFTAR PUSTAKA}

\section{Buku:}

Adjei, Eric. 2005. The Legalitiy of Humanitarian Intervention. Tesis. University of Georgia. hlm. 29

Adolf, Huala. 1990. Aspek-Aspek Negara dalam Hukum Internasional. Jakarta: Rajawali Press.

Andrea, Faustinus. 2006. Perimbangan Kekuatan di Myanmar Faktor ASEAN dan Kepentingan Indonesia. Vol. 35 No. 2 Juni 2006. Analisis Centre for Strategic and International Studies (CSIS). Jakarta.

Brierly, J. L. 1996. Hukum Bangsa-Bangsa: Suatu Pengantar Hukum Internasional. Jakarta: Bharata.

Cipto, Bambang. 2007. Hubungan Internasional di Asia Tenggara, Teropong terhadap Dinamika, Realitas, dan Masa Depan. Yogyakarta: Pustaka Pelajar.

D'Amato, Anthony. 2001. There is No Norm of Intervention or Non Intervention in International Law. International Legal Theory. ASIL.

Direktorat Jenderal Kerjasama ASEAN Departemen Luar Negeri Republik Indonesia. 2007. ASEAN Selayang Pandang. Jakarta: Departemen Luar Negeri Republik Indonesia.

Hall, D.G.E. 1981. The History of South-East Asia, Malaysia: Dewan Bahasa dan Pustaka Kuala Lumpur.

Herjuno, Muhammad. 2010. Pelaksanaan Prinsip Non Intervensi di ASEAN (Studi Kasus Myanmar), Yogyakarta: Universitas Islam Indonesia.

Istanto, F. Sugeng. 2007. Penelitian Hukum. Yogyakarta: Ganda.

KKelsen, Hans. 2007. General Theory of Law and State (alih bahasa Somardi). Jakarta: Bee Media. 
Kusumaatmadja, Mochtar. 1982. Pengantar Hukum Internasional. Bandung: Bina Cipta.

Liliansa, Dita. 2013. Hak Kewarganegaraan Etnis Rohingya. UNHCR, "Mencegah dan Mengurangi Keadaan tanpa Kewarganegaraan: Konvensi 1961 tentang Pengurangan Keadaan tanpa Kewarganegaraan".

Luhulima, CPT, dkk. 2008. Masyarakat Asia Tenggara menuju Komunitas ASEAN 2015, Jakarta: Pustaka Pelajar, Pusat Penelitian Politik-LIPI.

Mangku, Dewa Gede Sudika. 2012. Peran dan Tantangan Indonesia dalam Penegakan Hak Asasi Manusia di Kawasan Asia Tenggara (Studi Kasus Pelanggaran Hak Asasi Manusia terhadap Etnis Minoritas Rohingya oleh Pemerintah Myanmar). Jure Humano. Vol. 3. Nomor 7 November 2012.

Pramudito. 2013. Pelanggaran Prinsip Non intervensi. diakses pada www.beritasatu.com pada tanggal 28 Maret 2013.

Raharjo, Satjipto. 1980. Ilmu Hukum. Bandung: Alumni.

Samekto, FX. Adj. 2009. Negara dalam Dimensi Hukum Internasional. Bandung: Citra Aditya Bakti.

Starke, J. G. 2007. Pengantar Hukum Internasional (edisi kesepuluh, Buku 2). Jakarta: Sinar Grafika.

\section{Perjanjian Internasional:}

Piagam ASEAN.

Treaty of Amity and Cooperation in Southeast Asia 1976 (TAC).

\section{Website:}

Andrea, Faustinus. 2007. ASEAN Setelah 40 Tahun. diakses pada tanggal 23 Maret 2014, dari http: //www.kompas.com.

Anonim. 2007. US Wanst Myanmar on UN Agenda. diakses pada tanggal 23 Februari 2013. dari http: //english.aljazeera.net.

Anonim. 2008. Piagam ASEAN. diambil dari http: //skiasyik.wordpress.com/2008/03/25/aseancharter/ - _ftn3. pada tanggal 24 Maret 2014

Bandoro, Bantarto. 2003. Mahatir's Myanmar Policy Not Just Empty Rhetoric. The Jakarta Post. tanggal 29 Juli 2003.

Budiatno, Adityo. 2010. Prinsip Non Intervensi dan Prospek, diambil dari http://adityobudiatno.bl ogspot.com/2010/03/prinsip-nonintervensi-danprospek.html, pada tanggal 24 Maret 2014

Katsumata, Hiro. 2004. Why Is Asean Diplomacy Changing? From "Non-Interference" to "Open and Frank Discussions" Asian Survey, Vol. 44, No. 2 (Mar. - Apr., 2004). diambil dari http: //ezproxy.ugm.ac.id:2056/action/doBasicResu $1 \mathrm{t}$ hp $=25 \& \mathrm{la}=\& \mathrm{gw}=\mathrm{jtx} \& \mathrm{jcpsi}=1 \& \mathrm{artsi}=1 \& \mathrm{Qu}$ ery $=$ asean $\&$ sbq $=$ asean $\& \mathrm{si}=76 \& \mathrm{jtxsi}=76$, pada tanggal 23 Maret 2014.

Severino, Rodolfo. 1998. Asia Policy Lecture: What ASEAN Is and What It Stands For (The Research Institute for Asia and the Pacific, University of Sydney, Australia, 22 October 1998), diakses pada tanggal 7 Oktober 2008 dari http://www.aseansec.org/3399.htm. 